\title{
Nitrogen balance in relation to energy intake in entire male pigs weighing $75 \mathrm{~kg}$
}

\author{
BY A. C. DUNKIN \\ School of Agriculture and Forestry, University of Melbourne, \\ Parkville, Victoria 3052, Australia \\ AND J. L. BLACK AND K. J. JAMES \\ CSIRO, Division of Animal Production, PO Box 239, Blacktown, NSW 2148, Australia
}

(Received 19 December 1984 - Accepted 30 August 1985)

\begin{abstract}
1. Nitrogen balance (NB) was determined in entire male pigs weighing 75.6 (SE 0.56 ) $\mathrm{kg}$ and given $1.43 \mathrm{MJ}$ metabolizable energy $(\mathrm{ME}) / \mathrm{kg}$ live weight $(\mathrm{LW})^{0.75}$ per $\mathrm{d}$ of semi-synthetic liquid diets which varied in crude protein $(\mathrm{N} \times 6.38)$ : $\mathrm{ME}$ from 2.5 to $14.5 \mathrm{~g} / \mathrm{MJ}$. Maximum NB of $20.8 \mathrm{~g} / \mathrm{d}$ was reached with diets containing at least $6.2 \mathrm{~g}$ protein/MJ ME.

2. The relation between energy intake and NB was then examined in pigs of comparable live weight (mean 73.8 (SE 0.39) $\mathrm{kg}$ ) and receiving a liquid diet not limiting in protein. The diet, containing $10.0 \mathrm{~g}$ protein/MJ ME, was given at eight rates from $0.24 \mathrm{MJ} \mathrm{ME} / \mathrm{kg} \mathrm{LW}^{0.75}$ per d to ad lib. by approximately equal increments. Two animals were allocated to each level and two animals were fasted during the balance period.

3. The animals fed ad lib. achieved a mean intake of $1.84 \mathrm{MJ} \mathrm{ME} / \mathrm{kg} \mathrm{LW}^{0.75}$ per d. NB increased linearly as $\mathrm{ME}$ intake increased up to $27.6 \mathrm{MJ} / \mathrm{d}\left(1.096 \mathrm{MJ} / \mathrm{kg} \mathrm{LW} \mathrm{LW}^{0.75}\right.$ per d) but thereafter remained constant at $22.8 \mathrm{~g} \mathrm{~N} / \mathrm{d}$.
\end{abstract}

Nitrogen utilization in animals can be studied using either short-term experiments measuring $\mathrm{N}$ intake (NI) and $\mathrm{N}$ losses (balance studies) or experiments involving the slaughter of animals at the beginning and at the end of longer-term treatment periods. The former provides an estimate of $\mathrm{N}$ balance (NB) at a specific live weight (LW) whereas the latter provides an estimate of $\mathrm{N}$ retention (NR) which is the mean value for a considerable weight range. In the present paper, the terms NB and NR are used to distinguish between results derived from balance and slaughter experiments respectively.

The relation between energy intake and $\mathrm{N}$ utilization in the growing pig and the extent to which it is modified by stage of growth, sex and strain of pig is unclear. On the basis of limited information involving results from balance and slaughter experiments, the Agricultural Research Council (1981) concluded that the relation between energy intake and NR was probably linear. However, it was pointed out that most information was derived from young animals, that few experiments of appropriate design had been reported, and that the relation may be affected by the variables mentioned previously. While subsequent evidence supports the view that, in pigs weighing less than $20 \mathrm{~kg}$, NR responds linearly to energy up to high intakes (Campbell \& Dunkin 1983a,b), the relation in heavier pigs remains unclear.

The experiments reported involved pigs of approximately $75 \mathrm{~kg} \mathrm{LW}$. Dietary protein:energy necessary for maximum NB in pigs receiving a high-energy intake was first established. The response to increasing intakes of metabolizable energy (ME) was then determined using a diet that was not limiting in protein.

\section{METHODS AND MATERIALS}

In two experiments, NB was determined in Large White, entire male pigs given semi-synthetic liquid diets and held in metabolism crates. Room temperature was maintained close to $22^{\circ}$. 
Table 1. Compositions of diets*

\begin{tabular}{|c|c|c|c|c|c|}
\hline Diet no... & 1 & 3 & \multicolumn{2}{|c|}{5} & 8 \\
\hline \multicolumn{6}{|l|}{ Ingredients (g/kg DM) } \\
\hline Sodium caseinate & $68 \cdot 8$ & $160 \cdot 4$ & \multicolumn{2}{|c|}{$252 \cdot 0$} & $389 \cdot 4$ \\
\hline Dextrose & 407.0 & $352 \cdot 0$ & \multicolumn{2}{|c|}{296.6} & $214 \cdot 7$ \\
\hline Butter oil & $376 \cdot 0$ & $348 \cdot 4$ & \multicolumn{2}{|c|}{$321 \cdot 0$} & $279 \cdot 0$ \\
\hline Soya-bean oil & $94 \cdot 0$ & 87.1 & \multicolumn{2}{|c|}{$80 \cdot 2$} & $69 \cdot 7$ \\
\hline DL-Methionine & 0.7 & 1.6 & \multicolumn{2}{|c|}{2.6} & $4 \cdot 0$ \\
\hline Minerals $\dagger$ & $53 \cdot 5$ & $50 \cdot 5$ & \multicolumn{2}{|c|}{47.6} & $43 \cdot 2$ \\
\hline Choline & $2 \cdot 0$ & $2 \cdot 0$ & \multicolumn{2}{|c|}{$2 \cdot 0$} & $2 \cdot 0$ \\
\hline $\begin{array}{l}\text { Vitamins and trace } \\
\text { minerals } \ddagger\end{array}$ & + & + & \multicolumn{2}{|c|}{+} & + \\
\hline $\begin{array}{l}\text { Chemical composition } \\
(/ \mathrm{kg} D M)\end{array}$ & & & Expt 1 & Expt 2 & \\
\hline $\begin{array}{l}\text { Crude protein } \\
\text { (nitrogen } \times 6.38)(\mathrm{g})\end{array}$ & 66.0 & $151 \cdot 5$ & $253 \cdot 7$ & $255 \cdot 6$ & $370 \cdot 4$ \\
\hline Gross energy (MJ) & $26 \cdot 6$ & $26 \cdot 9$ & 27.5 & $27 \cdot 0$ & $27 \cdot 2$ \\
\hline $\mathrm{ME}(\mathrm{MJ})$ & $26 \cdot 1$ & $26 \cdot 2$ & $26 \cdot 1$ & $25 \cdot 7$ & $25 \cdot 0$ \\
\hline Crude protein (g/MJ ME) & $2 \cdot 5$ & $5 \cdot 8$ & $9 \cdot 7$ & $10 \cdot 0$ & 14.5 \\
\hline
\end{tabular}

DM, dry matter; ME, metabolizable energy.

* Diet nos. 2, 4, 6 and 7 were prepared by mixing appropriate proportions of diet nos. 1 and 3,3 and 5 , and 5 and 8 respectively. All diets were formulated to contain $200 \mathrm{~g} \mathrm{DM} / \mathrm{kg}$ as fed (determined values $190-199 \mathrm{~g}$ $\mathrm{DM} / \mathrm{kg}$ ) and contained $4 \mathrm{~g}$ formalin $/ \mathrm{kg} \mathrm{DM}$ as a preservative. Diets $1-8$ were given in Expt 1 , diet 5 was given in Expt 2.

$\dagger$ Comprised the following (excluding water of hydration) $\left(\mathrm{g}\right.$ ): $\mathrm{CaCO}_{3} 26$ (added directly to each animal's allowance of milk immediately before each feed), $\mathrm{KH}_{2} \mathrm{PO}_{4} 8.5, \mathrm{MgSO}_{4} 1.8, \mathrm{NaH}_{2} \mathrm{PO}_{4} 17 \cdot 2$ in diet 1 decreasing progressively to $6.9 \mathrm{~g}$ in diet 8 .

$\ddagger$ Vitamins: each pig received $2 \mathrm{ml} / \mathrm{d}$ of a solution which provided (mg): retinol 1.68 , cholecalciferol 0.025 , riboflavin $4 \cdot 8$, nicotinamide 40 , pantothenic acid 20 , pyridoxine $5 \cdot 0$, cyanocobalamin $0 \cdot 16$, pterolymonoglutamic acid $2 \cdot 0$, ascorbic acid $200 \cdot 0$. Trace minerals: each pig received $2 \mathrm{ml} / \mathrm{d}$ of a solution which provided (mg) $\mathrm{Fe} 80$, $\mathrm{Zn} \mathrm{40,} \mathrm{Mn} \mathrm{16,} \mathrm{Cu} 8$.

\section{Experimental design, diets and feeding}

Diets were formulated on a gross energy (GE) basis. The apparent digestible energy (DE) contents of the diets were determined during the experiments and these were converted to ME using the equation of Morgan et al. (1975) to estimate the energy content of urine.

In Expt 1, sixteen pigs, mean LW 75.6 (SE 0.55) kg at the mid-point of the balance period, were given diets ranging in crude protein $(\mathrm{N} \times 6.38)$ content from 2.5 to $14.5 \mathrm{~g} / \mathrm{MJ} \mathrm{ME}$ at rates calculated to provide $1.43 \mathrm{MJ} \mathrm{ME} / \mathrm{kg} \mathrm{LW}^{0.75}$ per $\mathrm{d}$. Two pigs were allocated randomly to each of the eight diets (Table 1).

In Expt 2, two animals were randomly allocated to each of eight levels of feeding of diet 5 , and two additional animals were fasted. Mean LW was 73.8 (SE 0.39) kg. Diet 5 contained a higher protein :energy value than was required for maximum NB in Expt 1 . Feeding levels ranged from 0.24 to $1.69 \mathrm{MJ} \mathrm{ME} / \mathrm{kg} \mathrm{LW}^{0.75}$ per $\mathrm{d}$ in six equal increments, and two pigs were fed to appetite. The fasted animals were given 1.33 MJ ME $/ \mathrm{kg} \mathrm{LW}^{0.75}$ per $\mathrm{d}$ before the measurement period.

\section{Management}

Pigs were penned individually and given a conventional meal diet containing $14.0 \mathrm{MJ}$ DE and $10.0 \mathrm{~g}$ lysine $/ \mathrm{kg}$ at a rate of $102 \mathrm{~g} / \mathrm{kg} \mathrm{LW}{ }^{0.75}$ per d from a LW of 53 and $45 \mathrm{~kg}$ in Expts 1 and 2 respectively.

In Expt 1, pigs were changed from meal to diet 5 over a period of $3 \mathrm{~d}$ immediately before 


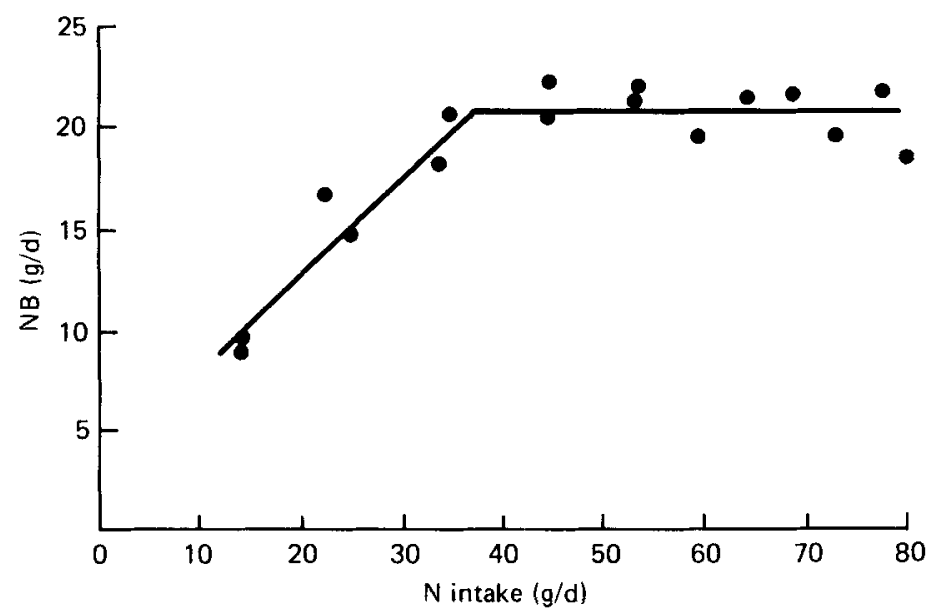

Fig. 1. Expt 1. Relation between nitrogen intake and $\mathrm{N}$ balance (NB). Each point represents one animal.

being moved to metabolism crates at a mean $\mathrm{LW}$ of $65.4 \mathrm{~kg}$. Experimental diets were introduced $2 \mathrm{~d}$ later and the collection period commenced after a further 9 or $10 \mathrm{~d}$.

In Expt 2, animals were transferred to the liquid diet at different live weights in accordance with the anticipated rate of weight change so that each would be of similar mean weight during the measurement period. Treatment regimens were in force for at least $10 \mathrm{~d}$ before the start of the collection period.

Pigs were weighed either on alternate days (Expt 1) or daily (Expt 2) in their tared crates. The animals were fed twice daily, with the amount of feed being adjusted in accordance with LW. Each metabolism crate was fitted with a reservoir from which the diet flowed by gravity to a nipple drinker located in the back of the feeding trough. Diet remaining in the reservoir or trough immediately before the following feed was removed and weighed. In Expt 2, the fasted pigs and those given the lowest intake were offered water.

The balance period lasted 7 d, except for three animals in Expt 2; for one animal it was $6 \mathrm{~d}$ and for the two fasted animals it lasted 8 and $9 \mathrm{~d}$ respectively.

\section{Collection and analysis of urine, faeces and feed}

Urine was collected by the method of Colebrook \& Black (1980). On the day collection commenced, or the previous day in the case of animals allocated to the highest two feeding levels, pigs were anaesthetized and fitted with a moulded latex pouch which covered the preputial area of the abdomen. Plastic tubing attached to the pouch removed urine under vacuum to the collection vessel which contained sufficient hydrochloric acid to maintain a $\mathrm{pH}$ of approximately 2 . Daily urinary output was recorded and $100 \mathrm{~g} / \mathrm{kg}$ samples were bulked for each pig and stored at $-15^{\circ}$. The small quantities of faeces voided were collected daily, bulked for each pig and stored at $-15^{\circ}$. A sample was taken of the liquid diet as each batch was homogenized, and the samples were bulked for subsequent analysis.

At the end of the experiment, faeces were thawed, a sample of approximately $50 \mathrm{~g}$ was taken for dry matter determination, and the remainder was freeze-dried before grinding in a laboratory mill. Sub-samples of the diet were freeze-dried. $N$ determinations were made on the diet, urine and faeces using a standard micro-Kjeldahl method. The GE contents of the diets and faeces samples were measured using an adiabatic bomb calorimeter. 


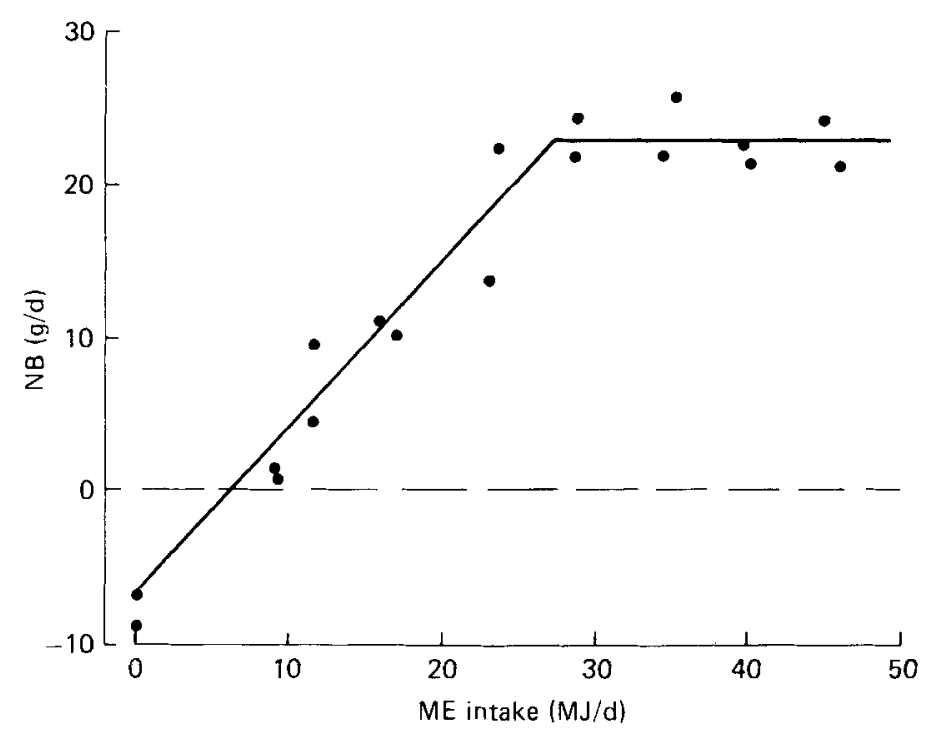

Fig. 2. Expt. 2. Relation between metabolizable energy (ME) intake and nitrogen balance (NB).

Each point represents one animal.

\section{Statistical analysis}

The relations between NB and NI (Expt 1), and NB and ME intake (Expt 2) were analysed by a piece-wise linear regression (Hudson, 1966), with the slope of the second phase being constrained to zero.

\section{RESULTS}

\section{Expt 1}

Except for two animals which, on $1 \mathrm{~d}$, refused 13 and $6 \%$ respectively of diets 7 and 8 , all allocated feed was consumed.

NB increased linearly with NI up to a daily intake of $36.5 \mathrm{~g} \mathrm{~N}(0.95$ confidence limits $27.5-43.8)$, attaining a maximum value of $20.8 \mathrm{~g} / \mathrm{d}(0.95$ confidence limits $19.2-22.4)$ (Fig. 1). Over the first phase of the relation, NB $(y, \mathrm{~g} / \mathrm{d})$ was related to NI $(x, \mathrm{~g} / \mathrm{d})$ by the equation:

$$
y=0 \cdot 48 x+3 \cdot 08 .
$$

The overall coefficient of determination, $r^{2}$, was 0.88 . The $\mathrm{N}$ intake of $36.5 \mathrm{~g} / \mathrm{d}$ was associated with a daily $\mathrm{ME}$ intake of $37.3 \mathrm{MJ}$ (i.e. $6.2 \mathrm{~g}$ protein $(\mathrm{N} \times 6.38) / \mathrm{MJ} \mathrm{ME})$.

\section{Expt 2}

Feed refusals during the balance period were negligible except for the two pigs fed ad lib. The latter achieved mean daily intakes of 9.5 and 9.3 litres/d (approximately $1.83 \mathrm{MJ} \mathrm{ME} / \mathrm{kg} \mathrm{LW}^{0.75}$ per d).

$\mathrm{NB}(y, \mathrm{~g} / \mathrm{d})$ responded linearly to ME intake $(x, \mathrm{MJ} / \mathrm{d})$ :

$$
y=1.07 x-6.63,
$$

up to a mean daily intake of $27.6 \mathrm{MJ}(0.95$ confidence limits $24.4-31.4)$; but thereafter remained constant at $22 \cdot 8 \mathrm{~g} / \mathrm{d}(0 \cdot 95$ confidence limits $21 \cdot 3-24 \cdot 2)$ (Fig. 2). Over the whole relation, $r^{2}$ was 0.96 . 


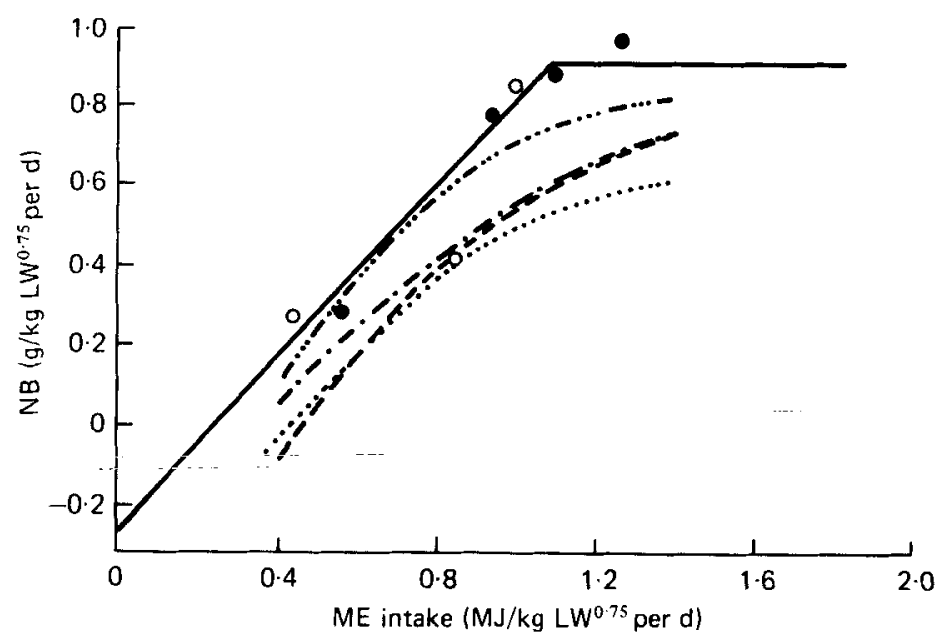

Fig. 3. Relation between metabolizable energy (ME) intake and nitrogen balance (NB) as reported by various authors: (1) mean NB values for individual treatment levels of $\mathrm{ME}$ intake for female, $60 \mathrm{~kg}$ live weight (LW) Large White cross (O) and Pietrain (O) pigs (Fuller et al. 1976); (2) regressions for German Landrace castrate pigs of (-_-) 69 and (..) $97 \mathrm{~kg} \mathrm{LW} \mathrm{(Expt} \mathrm{1)} \mathrm{and} 66\left({ }_{-} \ldots{ }_{-}\right)$) and $88(-\ldots .-$ ) kg LW (Expt 2) (Schneider et al. 1982); (3) regression, present study (-).

The regression lines depict the ranges of energy intake over which NB were determined on relations 2 and 3.

The mean coefficients (with SE) of apparent digestibility and metabolizability of the diet were 0.985 (SE 0.001) and 0.952 (SE 0.002) respectively.

\section{DISCUSSION}

In order to determine experimentally the relations between energy intake and either NB or NR the range of feeding levels must be wide and its upper limit must approach the animal's maximum capacity to ingest energy. Additionally, the diet must contain, relative to energy, sufficient protein, vitamins and minerals, to ensure that energy is the only factor limiting $\mathrm{N}$ utilization.

These criteria were met in Expt 2 in which feed intakes extended from fasting to approximately 4.0 times the energy required for maintenance, and the protein :energy value of the diet was not limiting NB. This ratio was substantially greater than that associated with maximum NB in Expt 1. Moreover in Expt 1, NB failed to respond to the higher levels of NI when these were associated with a greater intake of $\mathrm{ME}(37.3 \mathrm{MJ} / \mathrm{d})$ than that at which maximum NB occurred in Expt $2(27.6 \mathrm{MJ} / \mathrm{d})$. There is little possibility, therefore, that the plateau in NB at high feeding levels in Expt 2 was due to inadequate protein intake.

Our results are compared in Fig. 3 with NB from other published reports for pigs weighing $60 \mathrm{~kg}$ or more.

The results of Fuller et al. (1976) for female Large White cross and Pietrain pigs of $60 \mathrm{~kg}$ show an approximately linear response in NB with ME up to an intake of 1.0-1.2 MJ $\mathrm{ME} / \mathrm{kg} \mathrm{LW} \mathrm{W}^{0.75}$ per d. These results correspond closely with those reported here, but no information was obtained for intakes beyond that at which maximum NB occurred in the present study. More recently, Schneider et al. (1982) fitted curvilinear regressions to NB values from German Landrace castrate pigs. These studies involved six levels of feeding, which extended up to $1.4 \mathrm{MJ} \mathrm{ME} / \mathrm{kg} \mathrm{LW}^{0.75}$ per d, to pigs of 69 and $97 \mathrm{~kg}$ in one experiment 
and to pigs of 66 and $88 \mathrm{~kg}$ in a second experiment. As indicated in Fig. 3, there was little increase in NB once energy intake exceeded 1.2 MJ ME/ $\mathrm{kg} \mathrm{LW}{ }^{0 \cdot 75}$ per d.

There is a lack of information regarding the relation between NR and energy intake in heavier pigs. However, Campbell et al. (1985) recently reported that, between 45 and $90 \mathrm{~kg}$ live weight, the response of NR to graded intakes up to ad lib. of a high-energy, protein-adequate diet was linear/plateau in form in both entire male and female pigs. The results of both Schneider et al. (1982) and the present experiment indicate that, for pigs in the finisher stage of growth, the relation between NB and ME conforms to a linear/plateau model as proposed for NR and ME intake by Whittemore \& Fawcett (1976) and as found in the recent NR studies of Campbell et al. (1985). In contrast, for pigs of less than $20 \mathrm{~kg} \mathrm{LW}$, NR has generally been found to continue to increase linearly to high levels of feeding (e.g. Burlacu et al. 1973; Close et al. 1979; Campbell \& Dunkin 1983a,b), although Hodge (1974) reported no reduction in NR when milk intake was reduced from ad lib. by $20 \%$.

We suggest that the response in net protein deposition, as measured in $\mathrm{N}$ utilization studies, to an increase in ME intake for pigs of all weights is of the linear/plateau form, but that manifestation of the horizontal component depends on which of two factors, maximum rate of protein deposition or voluntary energy intake, is first limiting. Thus the continuing linearity of NR response in pigs weighing less than $20 \mathrm{~kg}$ can be explained if the potential for NR is high relative to appetite at this stage of growth. At some heavier weight, which is likely to vary with sex and strain of pig, voluntary energy intake exceeds that at which maximum NR is attained. For example, within a particular strain of pig, females appear to reach this point at a lighter weight than entire males (Campbell et al. 1983). Conversely, some extremely-lean genotypes may continue to show a linear NR response to energy intake up to normal slaughter weight. In order to determine feeding policies that are economically optimal, the response of NR to energy intake needs to be defined for pigs of different sex and strain at successive stages of growth. The two-stage approach adopted in the present study is more useful than that of measuring the response to arbitrarily-selected combinations of protein and energy intakes. In the latter case it is impossible to identify the separate effects of either nutrient and in consequence the information is of restricted value for predictive purposes.

One other aspect of the results from Expt 2 merits comment. A substantial quantity of $\mathrm{N}$ was retained in pigs given feed intakes that produced zero energy balance. NB was $5.7 \mathrm{~g} / \mathrm{d}$ $\left(0.22 \mathrm{~g} / \mathrm{kg} \mathrm{LW}^{0.75}\right.$ per d) when ME intake was $0.458 \mathrm{MJ} / \mathrm{kg} \mathrm{LW}^{0.75}$ per $\mathrm{d}$, the value suggested for zero energy balance by the Agricultural Research Council (1981). A similar finding was reported by Fuller et al. (1976) (Fig. 3) and has been observed in other species (Black, 1974; Ørskov et al. 1983).

The authors thank Messrs W. Brown, P. Eckermann and W. Colebrook for technical assistance. The financial support of the Australian Pig Industry Research Committee is gratefully acknowledged.

\section{REFERENCES}

Agricultural Research Council (1981). The Nutrient Requirements of Pigs. Slough: Commonwealth Agricultural Bureaux.

Black, J. L. (1974). Proceedings of Australian Society of Animal Production 10, 211-218.

Burlacu, G., Bain, G., Ionila, D., Moisa, D., Tascenco, V., Visan, I. \& Stoioa, J. (1973). Journal of Agricultural Science, Cambridge 81, 295-302.

Campbell, R. G. \& Dunkin, A. C. (1983a). British Journal of Nutrition 49, 221-230.

Campbell, R. G. \& Dunkin, A. C. (1983 b). Animal Production 36, 185-192.

Campbell, R. G., Taverner, M.R. \& Curic, D. M. (1983). Animal Production 36, 193-199.

Campbell, R. G., Taverner, M. R. \& Curic, D. M. (1985). Animal Production 40, 497-503 
Close, W. H., Stanier, M. W. \& Sanz Sampelayo, M. R. (1979). Proceedings of the Nutrition Society 39, 47A.

Colebrook, W. F. \& Black, J. L. (1980). Journal of Agricultural Science, Cambridge 95, 17-20.

Fuller, M. F., Webster, A. J. F., MacPherson, R. M. \& Smith, J. S. (1976). In Energy Metabolism of Farm Animals, European Association of Animal Production Publication no. 19, pp. 177-180 [M. Vermorel, editor]. Clermont Ferrand, France: European Association of Animal Production.

Hodge, R. W. (1974). British Journal of Nutrition 32, 113-126.

Hudson, D. J. (1966). Journal of American Statistical Association 61, 1097-1129.

Morgan, D. J., Cole, D. J. A. \& Lewis, D. (1975). Journal of Agricultural Science, Cambridge 84, 7-17.

Ørskov, E. R., MacLeod, N. A., Fahmy, S. T. M., Istasse, L. \& Hovell, F. D. De B. (1983). British Journal of Nutrition 50, 99-107.

Schneider, W., Gaus, G., Michel, A., Susenbeth, A. \& Menke, K. H. (1982). In Energy Metabolism of Farm Animals, European Association of Animal Production Publication no. 29, pp. 225-228. [A. Ekern and F. Sundstøl, editors]. Aas, Norway: European Association of Animal Production.

Whittemore, C. T. \& Fawcett, R. H. (1976). Animal Production 22, 87-96. 